\title{
English Abstracts
}

\section{Richard Collins: The BBC and "public value”, pp. 164-184}

The paper identifies the roots of 'public value' management in the work of the American scholar Mark Moore, describes its mediation to the UK and its adoption by the $\mathrm{BBC}$ as a regulatory as well as a management doctrine. The author proposes that the BBC's adoption of public value doctrine responds to critiques of the BBC's divergence from public service principles in its broadcasting practice and to the challenges of the contemporaneous review of the BBC's Charter. The paper describes the Work Foundation's public value model of authorisation, creation and measurement of public value and its application to the BBC. It evaluates the concepts of co-production and contestation (derived from Mark Moore) and reach, impact, quality and value for money (the four public value 'drivers' adopted by the BBC) and considers Hirschman's 'exit, voice and loyalty' model of institutional responsiveness to users and the applicability of the concepts 'consumer' and 'citizen' to the BBC's public value doctrine and practice. The paper concludes that the Moorean core concepts 'co-production' and 'contestation' are of limited applicability to the BBC and that the BBC's distinctive status and scale may limit the relevance of its pathbreaking implementation of public value management to other parts of the UK's public cultural sector.

Keywords: BBC, public value, co-production, contestation, UK public cultural sector, Work Foundation, Hirschman, four drivers - reach, impact, quality, value for money.

Thomas Hanitzsch / Klaus-Dieter Altmeppen: About comparing: Comparative research in German Communication Journals from 1948-2005 (Über das Vergleichen: Komparative Forschung in deutschen kommunikationswissenschaftlichen Fachzeitschriften 1948-2005), pp. 185-203

This study takes stock of more than 50 years of cross-national research in the three leading German communication journals Medien E Kommunikationswissenschaft (Rundfunk und Fernseben), Publizistik und Media Perspektiven. Despite a positive trend that started in the 1990s, the findings point towards a substantial disregard of basic standards in comparative methodology. Most of the articles analysed did not justify their comparative design and selection of countries. Furthermore cross-national research seems to be only rarely embedded in a theoretical or conceptual perspective; in fact, most of the articles coded were atheoretical. In addition to this, researchers tend to omit the issue of equivalence in data collection, which refers to the comparability in terms of methods and period of data collection, research tools, populations and sampling methods.

Keywords: Comparative research, methodological standards, content analysis

\section{Rudolf Stöber: From the Franco-German War (1870/71) up to World War II. War reporting between journalistic routines and political propaganda (Vom deutsch- französischen Krieg zum Zweiten Weltkrieg. Kriegsberichterstattung zwischen journalistischen Routinen und politischer Propaganda), pp. 204-222}

Which degree of autonomy can journalists preserve in war times? Reliable sources that give answers to this question are very rare and have to be considered carefully. By employing historical criticism - a method developed by historians from Leopold von 
Ranke, Gustav Droysen and others - this article examines war reporting during the last three great wars Germany has led (1870/71,1914-18 and 1939-54). Input and throughput of war reporting in German newspapers of different ideological positions are compared. Journalists' independence in war reporting is compared with regard to the three central functions of media: providing information, giving orientation and furthering opinion formation. The findings show significant differences that can be explained by the primary constraint of war reporting - political interest. In general, positive press policies pose the most dangerous influences on the status of journalistic autonomy - and not censorship as might be supposed. Finally, consequences of the history of war reporting on journalism research in general are considered.

Keywords: War reporting, press policy, media functions, journalism, propaganda, media history

Birgit Stark: Program choice in multimedia environments: The Electronic Program Guide as a gatekeeper? (Programmauswahl in digitalen Fernsehwelten: Der EPG als Gatekeeper? Ergebnisse einer Nutzerbefragung), pp. 223-246

In Germany the era of digital television began in the mid 1990s. In an amplified multichannel environment, an increase in the number of available programs as well as a greater variety of niche channels creates a new complexity of program choices. Along with the digitization of TV Electronic Program Guides (EPGs) were developed to help viewers navigate through the hundreds of channels. These EPGs offer new tools for selecting channels and have the potential to change the way users watch television. The current study explores the use and impact of Electronic Program Guides on television viewing behaviour. Empirical findings are based on a paper and pencil survey. More than 600 customers of a private cable network were interviewed by means of a standardized questionnaire. The findings confirm the key role of EPGs in digital broadcasting, as the use of the new tool leads to greater channel awareness and channel repertoire. Furthermore, the data show different patterns of consumption which are influenced by established viewing habits and search strategies. In conclusion, the results of the study provide some support for the idea that EPGs could be a gatekeeper in the digital television world.

Keywords: Digital television, Electronic Program Guide, TV exposure, program choice, selectivity, channel repertoire

Carsten Winter: Raymond Williams (1921-1988) - Media and communication research for the democratisation of culture and society (Raymond Williams 1921-1988 - Medien- und Kommunikationsforschung für die Demokratisierung von Kultur und Gesellschaft), pp. 247-264

This essay reconstructs the development of Williams' materialistic conceptualization of mediated communication, which was essentially determined by his interest in the democratisation of culture and society. Building on his "Culture \& Society" (1958), "The Long Revolution" (1960) and "Communications" (1962), he was to become one of the founding fathers of Cultural Studies and laid the groundwork for a new understanding of communication as a creative process in which people are able to mediate, construct, constitute and change their experiences and ways of living. Most exemplary of his work is the volume: "Television: Technology and Cultural Form" (1974). In his later works, he developed specific aspects of this complex cultural and materialistic process of com- 
munication with ever finer differentiations. In the context of current theories on flows, networks and connectivity in the field of culture and media, his writings have been regaining meaning.

Keywords: culture, democracy, cultural studies, technology, „mobile-“ and „plannedflow", cultural materialism, mass media critics, communication history 